\title{
Effect of Different Levels of Locust Meal on Growth, Feed Conversion and Carcass Composition for Nile Tilapia Fry (Oreochromis Niloticus)
}

\section{Mohammed FA' ${ }^{1}$, Suliman HMA ${ }^{2 *}$, Yousif RA ${ }^{1}$, Mohamed AA ${ }^{1}$, Alhafez AM$^{1}$ and Rahma $\mathrm{ME}^{1}$}

${ }^{1}$ Department of Fisheries and Wildlife Science, Sudan University of Science and Technology, Sudan

${ }^{2}$ Biology Department, Taibah University, Kingdom of Saudi Arabia

*Corresponding author: Hassan MA Suliman, Biology Department, College of Sciences, Taibah University, Medina, Kingdom of Saudi Arabia, Email: hassanadamus@yahoo.com
Research Article

Volume 4 Issue 2

Received Date: June 01, 2020

Published Date: June 19, 2020

DOI: $10.23880 /$ ijoac-16000188

\section{Abstract}

A seven weeks feeding trial was conducted to evaluate growth, feed utilization and body composition of Nile tilapia fry Oreochromis niloticus ( $8.45 \pm 1.73 \mathrm{~g} ; 9.36 \pm 0.2 \mathrm{~cm}$ ), fed four isonitrogenous ( $250 \mathrm{~g} \mathrm{~kg}-1$ crude protein) and isoenergetic (16.67 kJ g-1 Gross energy) diets in which the main protein contributors were: diets containing replacement levels of $0,25,50$ and $100 \%$ of Fish Meal (FM) digestible protein by Locust Meal LM digestible protein. The experimental design was completely randomized with four treatments and three replicates. Fish were stocked in triplicate groups of 20 fish held in $70 \mathrm{~L}$ flow through tanks (water volume $55 \mathrm{~L}$ ) and fed twice daily $(08: 00$ a.m and 04;30 pm) to apparent satiation. Fish fed diet I exhibited the highest $(\mathrm{P}<0.05)$ values for live weight gain and specific growth rate $(\%$ per day). FCR and SGR were better $(\mathrm{P}<0.05)$ in fish-fed diets T0 and T2. Fish-fed diet T1 exhibited lower $(\mathrm{P}<0.05)$ fat and ash contents in carcass. The protein efficiency ratio, absolute body weight live weight gain and feed conversion ratio content significantly decreased in fish fed diets containing LM levels $100 \%$. Therefore, LM can replace up to $25 \%$ of FM without impairing juvenile Nile tilapia growth performance, feed efficiency and body composition.

Keywords: Growth performance; Locust; Orechromis niloticus; Replacement

\section{Introduction}

Tilapia is one of the most popular aquaculture species and is farmed in more than 120 countries and territories. However, global tilapia aquaculture production is highly imbalanced, with the top ten countries in 2015 accounting for over 90 percent of the 5.7 million tonnes of global production [1]. Tilapia is second-most important cultured finfish worldwide and farmed globally by many small holders. Nile tilapia (Oreochromis niloticus) ranks 6th among the most important cultured species, providing food, jobs, domestic and exporting earnings. Tilapia is an important protein source especially for poor consumer because they are an omnivorous diet, are tolerant to high density in aquaculture and relatively diseases resistant [2].

Fishmeal is recognized by nutritionist as high quality, very digestible feed ingredient that is favored for addition to the diet of most farm animals, especially fish and shrimp. Fishmeal carries quantities of energy per unit weight and excellent source of protein, lipids, minerals and vitamins, carbohydrate very little in fishmeal [3].

Locusta are certain spp of short horned in the family 
acrididae that have swarming phase. These insects are usually solitary but under certain circumstances become more abundant and change their behavior and habits becoming gregarious. No taxonomic distinction is made between locust and grasshopper spescises [4]. Several cultures throughout the world consume insects and and locusts are considered a delicacy and eaten in many African, middle eastern and Asian countries. They have been used as food throughout history, they can be cooked in many wise but are often frid, smoked or dried Culture fish required protein, lipid, energy, vitamins and minerals in their diet for growth, reproduction, and other normal physiological functions. Nutrients for culture may come from various feed source, such as plankton, bacteria, insects and other fish from within the aquaculture ecosystem, and organic matter and processed feeds added to the ecosystem $[5,6]$. Natural foods are the best foods for fish and include algae (phytoplankton), zooplankton, detritus, snails, worms, insects and insect larvae, small plants like duckweeds and various other weeds and grasses that are found in a fish pond [7].

Locusts, like many insects are an excellent source of protein, some species of locusts vary in protein content from 50 percent of dry weight to almost $60 \%$ percent, making them denser in protein than cows. The protein of some species of locust is not considered complete because it is of missing of the some essential amino acids [4].

Locusts also contain adequate amounts of iodine, phosphorus, iron, thiamine, riboflavin, niacin and carbohydrate levels are very low in locusts. The Nile tilapia belongs to the taxonomic family of the Cilchlidae. Cichlids are one of the most species rich fish families comprising more than 1600 valid taxa [8]. These include the important aquaculture species Oreochromis niloticus [8,9]. With regard to the total sulphur amino acids (namely tyrosine, cystine, methionine and phenylalanine), tyrosine and cystine are best considered semi-essential in that, the fish can utilize cystine as a precursor for the biosynthesis of methionine and phenylalanine, thus reducing the dietary requirement for these two essential amino acids. The optimum gross dietary lipid requirements for Nile tilapia ranges between 10 and 15 percent [10]. To determine the effect of different level of locust meal on growth performance in Nile tilapia Oreochromis niloticus fingerlings. The aim of study to determine the effect of different level of locust meal on chemical composition of studied fish.

\section{Materials and Methods}

\section{Preparation of Experimental Diets}

In this study, firstly proximate composition of the ingredients used in fish feeds were analyzed Table 1 and then feasibility of replacing fishmeal with locust meal protein for Nile tilapia Oreochromis niloticus fry were find out. In this experiment four isonitrogenous $(25 \% \mathrm{CP})$ and isocaloric (16.67 kj/g) diets replacing 0\% (T0), 25\% ( T1), 50\% (T2) and $100 \%$ (T3) fishmeal protein by Locust meal protein were formulated Table 1 . All diets were isonitrogenous $(25 \%$ crude protein); out of which $10 \%$ protein was contributed by fish meal.

\begin{tabular}{|c|c|c|c|c|}
\hline Ingredients (g/ 100 g dry diet) $^{-}$ & T0 (0\%) & T1 (25\%) & T2 (50\%) & T3 (100\%) \\
\hline Fish meal $^{1}$ & 18.52 & 14.11 & 9.26 & 0 \\
\hline Locust meal $^{2}$ & 0 & 3.8 & 9.26 & 18.52 \\
\hline Groundnut Cake $^{3}$ & 9.26 & 9.26 & 9.26 & 9.26 \\
\hline Wheat bran $^{4}$ & 36.5 & 36.5 & 36.5 & 36.5 \\
\hline Wheat middling $^{5}$ & 29.4 & 29.4 & 29.4 & 29.4 \\
\hline Vig-Oil $^{6}$ & 3 & 3 & 3 & 3 \\
\hline Mineral premix $^{7}$ & 2 & 2 & 2 & 2 \\
\hline Vitamin premix $^{8}$ & 2 & 2 & 2 & 2 \\
\hline Total $_{\text {Protein C.P (\%) }}$ & $\mathbf{1 0 0}$ & $\mathbf{1 0 0}$ & $\mathbf{1 0 0}$ & $\mathbf{1 0 0}$ \\
\hline E.E\% & $25.0 \pm 0.3$ & $25.00 \pm 0.0$ & $25.00 \pm 0.2$ & $25.8 \pm 0.05$ \\
\hline Ash\% & $3.6 \pm 0.07$ & $3.6 \pm 0.07$ & $3.1 \pm 0.21$ & $3.6 \pm 0.07$ \\
\hline Calculated gross energy (kJ g-1 dry diet) & $12.0 \_ \pm 0.0$ & $13.5 \pm 0.71$ & $11.5 \pm 0.71$ & $13.5 \pm 0.71$ \\
\hline
\end{tabular}

Table 1: Diet composition of the experiment.

${ }^{1}$ Fishmeal 54\% CP; ${ }^{2}$ Locust meal 52.39\%; ${ }^{3}$ Groundnut Cake 39\% CP; ${ }^{4}$ Wheat bran $13.7 \%$; ${ }^{5}$ Wheat Middling $17 \%$ CP, ${ }^{6}$ Vigetable oil (sunflower oil) and ${ }^{7}$ Mineral mixture (g/100g dry diet) calcium biphosphate 13.57; calcium lactate 32.69; ferric citrate 02.97; magnesium sulphate 13.20; potassium phosphate (dibasic) 23.98; sodium biphosphate 08.72; sodium chloride 04.35 ; almunium chloride. $6 \mathrm{H}_{2} \mathrm{O} 0.0154$; potassium iodide 0.015 ; cuprous chloride 0.010 ; mangnous sulphate $\mathrm{H}_{2} 0$ 0.080; cobalt chloride. $6 \mathrm{H}_{2} \mathrm{O} 0.100$; zinc sulphate. $7 \mathrm{H}_{2} \mathrm{O} 0.40$ (Halver, 2002). ${ }^{8}$ Vitamin mixture (g/100 dry diet) choline chloride 0.500 ;inositol 0.200 ; ascorbic acid 0.100 ; niacin 0.075 ; calcium pantothenate 0.05 ; riboflavin 0.02 ; menadione 0.004 ; pyridoxine hydrochloride 0.005 ; thiamin hydrochloride 0.005 ; folic acid 0.0015; biotin 0.0005; alpha-tocopherol 0.04; vitamin $B_{12}$ 0.00001; LobaChemie, India (Halver, 2002). 
Crude protein content in the diet was fixed at $25 \%$ on the basis of earlier available information [11]. All the ingredients were weighed and blended in a Hobart electric mixer thoroughly. These were then steam cooked at $80^{\circ} \mathrm{C}$ in a volume of hot water. Oil, mineral and vitamin premixes were added to the lukewarm bowl one by one with constant mixing at $60^{\circ} \mathrm{C}$. The final diet with bread dough consistency was poured into a teflon-coated pan, cut in the form of small cubes and stored until used.

\section{Experimental System and Animals}

Fry of Oreochromis niloticus were procured from Hussien Fadoul Fish Farm, Soba-Khartoum, Sudan. These were transported to hatchery of the Department of fisheries and Wildlife Science, Sudan University of Science \& Technology, Khartoum, Sudan, transport of fry in polyethylene sac and stocked in fiber glass for two days in this period fry no feed. After that use of small deep net to caught fry and then weight the fry and standardized then transfered to medium aquarium and circular pond.

During this period, the fish were fed to apparent satiation by feeding diet consisting of ground nut cake, wheat bran and wheat middling in the form of dried powder diet twice a day at 08:00 a.m. and 04:30 p.m.. For conducting the experiments, Oreochromis niloticus fry $(8.45 \pm 1.73 \mathrm{~g}$; $9.36 \pm 0.2 \mathrm{~cm}$ ) for experiment. were sorted out from the above acclimated lot and stocked in triplicate groups in 70-L circular polyvinyl tanks (water volume $20 \mathrm{~L}$ ) fitted with a continuous water flow-through (1-1.5 L min-1) system at the rate of 20 fish per tank for each dietary treatment. Fish were fed test diets in the form of powder diet to apparent satiation twice daily. No feed was offered to the fish on the day they were weighed. Initial and weekly weights were recorded on a top-loading balance. The feeding trial lasted for seven weeks. Faecal matter and unconsumed feed, if any, were siphoned off. The unconsumed feed was filtered on a screen soon after active feeding, dried and weighed to measure the amount of feed consumed.

\section{Water Quality Parameters}

Water temperature, dissolved oxygen, $\mathrm{NO}_{2}, \mathrm{NO}_{3}, \mathrm{pH}$, and total ammonia during the feeding trial were recorded following standard methods [12]. The range of water temperature, dissolved oxygen and $\mathrm{pH}$, over the seven weeks feeding trial, based on weekly measurements, were 25.60$29.40{ }^{\circ} \mathrm{C}, 4.06-5.55 \mathrm{mg} \mathrm{L}^{-1}$ and 7.7-8.27, respectively Table 3 .

\section{Proximate Analysis}

Assessment of proximate composition and fatty acid profile of ingredients, diets and carcass was made using standard techniques [13]. All the analyses were done on quadruplet basis $(n=4 \times 1)$. Details for each analysis are as under:

\section{Growth Parameters}

The effects of replacing fishmeal with water spinach in diets on growth and conversion efficiency of fingerling Oreochromis niloticus during the present experiment was evaluated using following indices:

Live weight gain (LWG; \%) = Final individual body weightInitial individual body weight/Initial individual body weight $\times 100$

Absolute weight gain $(\mathrm{g} / \mathrm{fish})=$ Final individual body weightInitial individual body weight

Feed conversion ratio $($ FCR $)=$ Dry feed fed/Wet weight gain

Protein efficiency ratio $($ PER $)=$ Weight gain $/$ Protein fed

Specific growth rate (SGR; \%/day) = ln Final body weight-ln Initial body weight/No. of days $\times 100$

Per cent survival $=($ Final number of fish $/$ Initial number of fish) $\times 100$

The proximate content analysis of carcass and feed was done. The results from the replicates for each feed samples were used to provide the data for the statistical analysis. All growth data were subjected to analysis of variance, differences among treatment means were determined by Duncan's Multiple Range Test at a $\mathrm{P}<0.05$ level of significance [14].

\section{Results}

\section{Growth Performance}

Excellent performance in terms of absolute weight gain (AWG; $\mathrm{g} \mathrm{fish}^{-1}$ ), feed conversion ratio (FCR) and (SGR) were observed for the groups fed dietary locust meal at $50 \%$ of the $\operatorname{diet}($ Table 2).

\begin{tabular}{|c|c|c|c|c|}
\hline & $\mathbf{T}_{0}$ & $\mathbf{T}_{1}$ & $\mathbf{T}_{2}$ & $\mathbf{T}_{3}$ \\
\hline IW (g) & $7.91 \pm 0.37^{\mathrm{c}}$ & $6.70 \pm 0.48^{\mathrm{d}}$ & $10.81 \pm 1.83^{\mathrm{a}}$ & $8.36 \pm 0.65^{\mathrm{b}}$ \\
\hline FW (g) & $11.41 \pm 0.62^{\mathrm{b}}$ & $9.30 \pm 0.48^{\mathrm{d}}$ & $14.46 \pm 2.18^{\mathrm{a}}$ & $10.60 \pm 0.69^{\mathrm{c}}$ \\
\hline AWG (g) & $3.50 \pm 0.95^{\mathrm{a}}$ & $2.60 \pm 0.05^{\mathrm{b}}$ & $3.64 \pm 0.99^{\mathrm{a}}$ & $2.24 \pm 1.13^{\mathrm{b}}$ \\
\hline
\end{tabular}




\begin{tabular}{|c|c|c|c|c|}
\hline LWG \% & $144.76 \pm 14.32^{\mathrm{a}}$ & $139.01 \pm 4.01^{\mathrm{a}}$ & $134.23 \pm 9.40^{\mathrm{b}}$ & $127.78 \pm 16.18^{\mathrm{c}}$ \\
\hline ADWG & $0.085 \pm 0.03^{\mathrm{b}}$ & $0.065 \pm 0.003 \mathrm{c}$ & $0.091 \pm 0.025^{\mathrm{a}}$ & $0.056 \pm 0.002^{\mathrm{d}}$ \\
\hline SGR & $0.401 \pm 0.10^{\mathrm{a}}$ & $0.360 \pm 0.031^{\mathrm{b}}$ & $0.320 \pm 0.007^{\mathrm{c}}$ & $0.260 \pm 0.13^{\mathrm{d}}$ \\
\hline FCR & $1.77 \pm 0.023^{\mathrm{b}}$ & $2.38 \pm 0.05^{\mathrm{a}}$ & $1.72 \pm 0.52 \mathrm{~b}$ & $2.76 \pm 0.35^{\mathrm{a}}$ \\
\hline Survival \% & 98 & 100 & 100 & 100 \\
\hline
\end{tabular}

Table 2: Growth, survival and feed utilization of Nile tilapia fed experimental diets.

a,b,c Mean values followed by the same superscript in each row are not significant different $(p>0.05)$

From tha above table the highest Absolute weight gain was recorded in $\mathrm{T}_{2}(3.64 \mathrm{~g})$, which was followed by $\mathrm{T}_{0}(3.50$ g), $T_{1}(2.60 \mathrm{~g})$ whereas, the lowest Absolute weight gain was
$\mathrm{T}_{3}(2.24 \mathrm{~g})$ Figure 1. The best FCR was in T2 (1.72), this was followed by T0 (1.77), T1 (2.38), and in T3 (2.76) Figure 2.

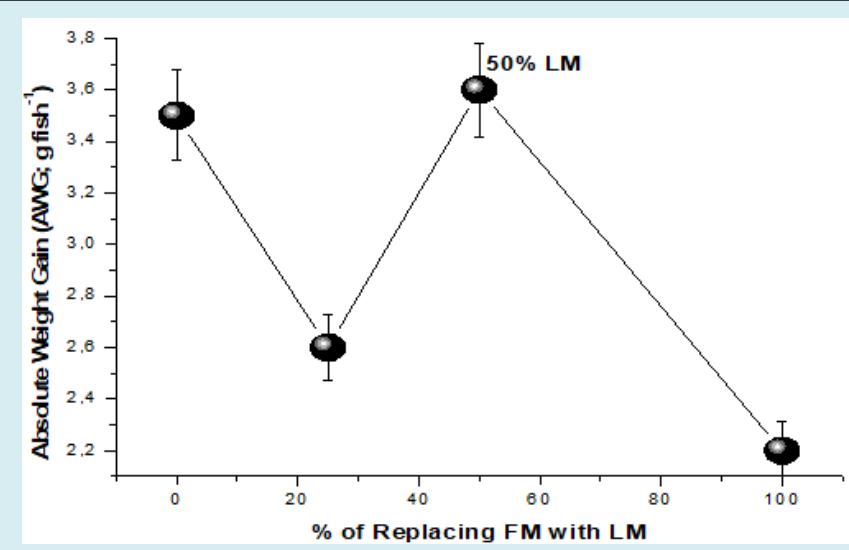

Figure 1: Relationship between the substitution rate of FM with LM and AWG ( $\mathrm{g} \mathrm{Fish}^{-1}$ ).

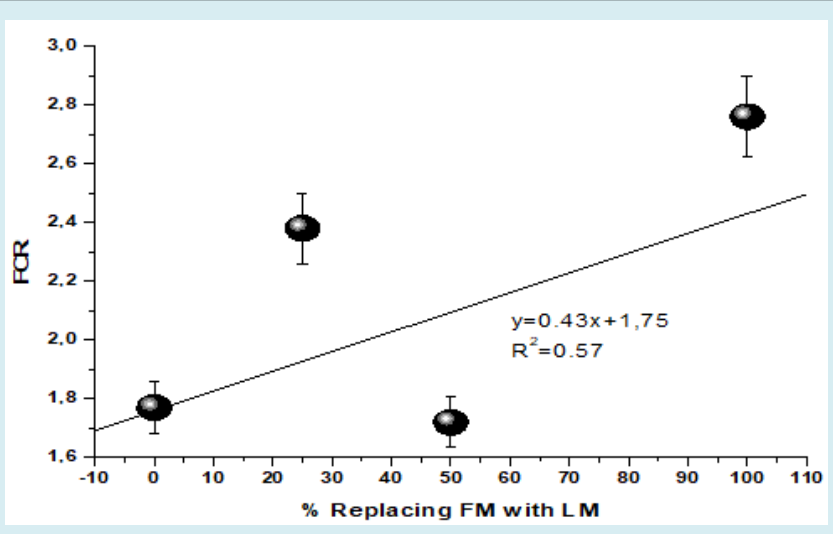

Figure 2: Relationship between the substitution rate of FM with LM and FCR.

\begin{tabular}{|c|c|c|c|c|}
\hline & $\mathbf{T}_{0}$ & $\mathbf{T}_{1}$ & $\mathbf{T}_{2}$ & $\mathbf{T}_{3}$ \\
\hline $\mathrm{pH}$ & $7.7 \pm 0.34^{\mathrm{b}}$ & $7.7 \pm 0.50^{\mathrm{b}}$ & $7.8 \pm 0.47^{\mathrm{b}}$ & $8.27 \pm 0.35^{\mathrm{a}}$ \\
\hline Ammonia & $0.22+0.19^{\mathrm{a}}$ & $0.22+0.19^{\mathrm{a}}$ & $0.22 \pm 0.19^{\mathrm{a}}$ & $0.22 \pm 0.19^{\mathrm{a}}$ \\
\hline $\mathrm{NO}_{2}$ & $0.01 \pm 0.00^{\mathrm{a}}$ & $0.00+0.00^{\mathrm{a}}$ & $0.00 \pm 0.00^{\mathrm{a}}$ & $0.01 \pm 0.00^{\mathrm{a}}$ \\
\hline $\mathrm{NO}_{3}$ & $160.0 \pm 0.00^{\mathrm{a}}$ & $7.57 \pm 1.86^{\mathrm{b}}$ & $4.0 \pm 0.00^{\mathrm{c}}$ & $4.0 \pm 0.00^{\mathrm{c}}$ \\
\hline DO & $5.55 \pm 2.29^{\mathrm{a}}$ & $4.06 \pm 0.33^{\mathrm{b}}$ & $5.09 \pm 1.63^{\mathrm{a}}$ & $5.42 \pm 1.90^{\mathrm{a}}$ \\
\hline Temperature & $29.60 \pm 0.50^{\mathrm{a}}$ & $29.40 \pm 0.51^{\mathrm{a}}$ & $25.60 \pm 0.53^{\mathrm{b}}$ & $26.23 \pm 0.51^{\mathrm{b}}$ \\
\hline
\end{tabular}

Table 3: Mean physical-chemical parameters of the test concentrations Locust meal on Water Quality.

$a, b, c$ Mean values followed by the same superscript in each row are not significant different $(p>0.05)$. 


\begin{tabular}{|c|c|c|c|c|}
\hline \multicolumn{5}{|c|}{ Experimental diets } \\
\hline & $\mathbf{T}_{\mathbf{0}}$ & $\mathbf{T}_{\mathbf{1}}$ & $\mathbf{T}_{\mathbf{2}}$ & $\mathbf{T}_{\mathbf{3}}$ \\
\hline DM\% & $18.0 \pm 5.66^{\mathrm{c}}$ & $28.0 \pm 2.83^{\mathrm{a}}$ & $27.0 \pm 2.83^{\mathrm{a}}$ & $25.5 \pm 2.12^{\mathrm{b}}$ \\
\hline Fat\% & $7.1 \pm 0.07^{\mathrm{a}}$ & $6.7 \pm 0.14^{\mathrm{b}}$ & $6.6 \pm 0.07^{\mathrm{b}}$ & $7.0 \pm 0.07^{\mathrm{a}}$ \\
\hline CP\% & $69.5 \pm 0.50^{\mathrm{a}}$ & $68.43 \pm 0.40^{\mathrm{a}}$ & $67.05 \pm 0.50^{\mathrm{a}}$ & $61.95 \pm 0.2^{\mathrm{b}}$ \\
\hline Ash & $3.05 \pm 1.34^{\mathrm{c}}$ & $4.6 \pm 0.77^{\mathrm{a}}$ & $4.0 \pm 0.00^{\mathrm{a}}$ & $2.0 \pm 0.00^{\mathrm{b}}$ \\
\hline
\end{tabular}

Table 4: Whole-body Composition or Carcass Composition of fry Nile tilapia Oreochromis niloticus fed graded concentrations of Locust meal for 7 weeks.

Means in the same row with different superscripts are significantly $(\mathrm{P}<0.05)$ different.

The results of whole body content or the carcass composition very important for nutritional value of Nile tilapia. In table 4 dry matter in the experimental ranged from 18.0 to 28.0. The fat in body ranged between $6.6 \%$ in $\mathrm{T}_{2}$ to $7.1 \%$ in $\mathrm{T}_{0}$. Crude protein in body of fish depended to essential amino acid in the diets. Generally, crude protein decrease with decrease of fish meal, high Crude protein in $\mathrm{T}_{0}(69.5 \%)$ and lower crude protein in $\mathrm{T}_{3}(61.95 \%)$. The Ash content between 2.0 to 4.6 .

\section{Discussion}

Selection of feed ingredients is one of the most important factors for the formulation and commercial production of supplemental quality feed for any aquatic species $[15,16]$. Although, fish meal is the widely used feed ingredients as animal protein source and accepted for its higher protein composition and essential amino acids; but it is rather expensive than the available plant protein sources [17]. Beside this, the availability of fish meal is decreasing day by day due to its high demand in other than aquaculture industry like livestock, poultry etc. The decreased supply of fish meal in future will dramatically affect the fish production. Considering this, it is essential to partially reduce or eliminate fish meal in fish diet. One approach to reduce fish meal from fish diets is to replace it with alternative less expensive and easily available protein, which will allow for continued expansion of aquaculture. In view of this, a number of plant and animl protein source has been evaluated for the replacement of fish meal [18-20]. Growth rate measured on weight of all fish in the aquarium weekly at seven week. High weight in final week, in the present study, there were no significant differences in AWG, LWG and SGR between these treatments, but there was a difference in survival, suggesting that locust meal significantly affected survival and the growth of Nile tilapia fry in Aquarium. Although this is the first study to report the effects of locust meal on $O$. niltoticus fry growth and survival in the Sudan.

In the present study, the inputs of fishmeal replacement with locust meal (0-100\%) have been evaluated on Nile tilapia fry. The highest absolute weight gain and SGR was noticed in
T2 in which replacement of fish meal with $50 \%$ of locust meal Table 2, as compared to other treatments. Similar results were also reported by Brah, et al. [21] FCR linearly increased and were significanlty affected by the treatments $(\mathrm{p}<0.05)$. Four isonitrogenic and isocaloric diets which contained 100$75 \%$ fish meal. After 7 weeks feeding period, weight gain, feed conversion ratio and survival rate compared to fish fed of all the treatment $(\mathrm{p}<0.05)$ in the present study, the highest absolute weight gain was recorded in $\mathrm{T} 2$ which was followed by $\mathrm{T} 0, \mathrm{~T} 1, \mathrm{~T} 3$ respectively. The recorded absolute weight gain was statistically different between treatments. SGR was not significantly, highest was in the T0, whereas the lowest SGR $(0.260)$ was found in T3. The best FCR was in the T2 replacement of the fish meal by $50 \%$ of locust meal followed by T0, T1 and T3 respectively Figure 2 . Thus, best growth of Nile tilapia fry was reported when fed with the T2 (5\%). Nile tilapia provided the diet with 50 per cent replacement of fish meal with locust meal attended an average weight of $14.46 \pm 2.18$ which was reported to be the highest in fish meal replaced diet. Thus, fish meal replaced by locust meal had effect on growth of Nile tilapia compared to the result [21].

\section{Conclusion}

The experiment showed that feeds were actively consumed by the experimental fish; Nile tilapia which brought an increase in weight. Since there was no significant difference $(\mathrm{P}>0.05)$ among the means of the treatments, it shows that any of the inclusion level can be used up to $50 \%$ inclusion level of locust meal. However, $50 \%$ inclusion level of locust meal produced best result in terms of growth. It is therefore recommended that locust meal can be incorporated at $50 \%$ inclusion without compromising fish growth. There are various alternative protein sources that can be used in aquaculture diets, without affecting growth performance, feed efficiency, and body composition, since the amino acids requirement is considered, locust meal can be used as alternative protein ingredient in fish feed.

\section{Declaration of Competing Interest}

There is no conflict of interest to declare between the 
authors of this manuscript.

\section{Acknowledgement}

The authors are grateful to the Dean, College of Animal Production Science and Technology and the head department of Fisheries and Wildlife Science, Sudan University of Science \& Technology for providing necessary laboratory facilities and also the assistance rendered by Hussien Fadoul Fish hatchery (Soba Agriculture Scheme-Sudan) for providing us the Nile Tilapia and also technical staff Depatment of Fisheries and Wildlife Science for their assistance in laboratory work namely: Mr. Ahmed Babay and Ms. Abeer Musa.

\section{References}

1. FAQ (2018) Notes from the Aquaculture Statistician. Food and Agriculture Organization of the United Nations, Rome, pp: 6-8.

2. FAO (2017) Tilapia Lake Virus (TiLV) Caused by an Orthomyxo-like virus (Family Orthomyxoviridae) Threatening Cultured and Wild Stocks of Tilapia. Food and Agriculture Organization of the United Nations, Rom, September- Newsletter No. 57, pp: 1-64.

3. Miles RD, Chapman RD (2015) The Benefits of Fish Meal in Aquaculture Diets. UF/IFAS Extension Service, pp: 1-7.

4. Simpson SJ, Sword GA, Loof AD (2005) Advances, Controversies and Consensus in Locust Phase Polyphenism Research. J Orthoptera Research 14(2): 213-222.

5. Csaba H (2011) Fish Nutrition and Feeding, Publication date- 31 August 2011, Responsible for content: TÁMOP4.1.2-08/1/A-2009-0059 project consortium, B-23, Kaposvár University.

6. Zafar N, Khan MA (2019) Effects of dietary iron on growth, haematology, oxidative stress and hepatic ascorbic acid concentration of stinging catfish Heteropneustes fossilis. Aquaculture 516: 734642.

7. Water Research Commission (2010) A Manual for Rural Freshwater Aquaculture Rural Fisheries Programme Department of Ichthyology and Fisheries Science Rhodes University and Department of Agriculture, Forestry and Fisheries WRC Report NO. TT 463/P/10, pp: 1-100.

8. Dunz AR, Schliewen UK (2013) Molecular phylogeny and revised classification of the haplotilapiine cichlid fishes formerly referred to as "Tilapia". Mol Phylogenet Evol 68(1): 64-80.

9. Schwarzer J, Misof B, Tautz D, Schliewen UK (2009) The root of the East African cichlid radiations. BMC Evol Biol 9: 186.

10. White PG, Shipton TA, Bueno PB, Hasan MR (2018) Better management practices for feed production and management of Nile tilapia and milkfish in the Philippines. FAO Fisheries and Aquaculture Technical Paper No. 614. Rome, FAO, pp: 96.

11. Abdelghany AE (2000) Optimum dietary protein requirements for Oreochromis niloticus L. fry using formulated semi purified diet. In: Fitzsimmons $\mathrm{K}$ and Filho JC (Eds.), Tilapia aquaculture in $21^{\text {st }}$ century. Proc from the 5th Intl Symp on Tilapia in aquaculture, pp: 101-108.

12. American Public Health Association (1992) Standard Methods for Examination of Water and Wastewater. $18^{\text {th }}$ (Edn.), APHA, AWWA, WPCF, NY, Washington DC.

13. AOAC (1995) Official Methods of Analysis. 16 $6^{\text {th }}$ (Edn.). Association of Official Analytical Chemists, Washington DC.

14. Duncan DB (1955) Multiple Range and Multiple F-Test. Biometrics 11: 1-5.

15. Zamal H, Barua P, Uddin B, Islam KS (2008) Application of ipil-ipil leaf meal as feed Ingredient for monosex tilapia fry (Oreochromis niloticus) in terms of growth and economics. Aquaculture Asia magazine, pp: 31-33.

16. Koumi AR, Atse BC, Kouame LP (2009) Utilization of soya protein as an alternative protein source in Oreochromis niloticus diet: Growth performance, feed utilization, proximate, composition and organoleptic characteristics. African Journal of Biotechnology 8(1): 91-97.

17. Vechklang K, Boonanuntanasarn S, Ponchunchoovong S, Pirarat N, Wanapu C (2011) The potential for rice wine residual as an alternative protein source in apractical diet for Nile Tilapia (Oreochromis niloticus) at the juvenile stage. Aquaculture Nutrition 17(6): 685-694.

18. Alceste CC, Jory DE (2000) Tilapia- Alternative protein sources in tilapia feed formulation. Aquaculture Magazine 26(4): 199-1388.

19. Yue YR, Zhou QC (2008) Effect of replacing soybean meal with cottonseed meal on growth, feed utilization, and hematological indexes for juvenile hybrid tilapia, Oreochromis niloticus $\times$ O. aureus. Aquaculture 284(1-4): 185-189.

20. Halver JE (2002) The vitamins and Minerals. In: Halver JE, Hardy RW, (Eds.), Fish nutrition, $3^{\text {rd }}$ (Edn.), Academic Press, San Diego, pp: 839. 
International Journal of Oceanography \& Aquaculture

21. Brah N, Houndonougbo FM, Issa S (2018) Grasshopper meal (Ornithacris cavroisi) in broiler diets Niger:
Bioeconomic Performance. Int J Poult Sc 17(3): 126-133.

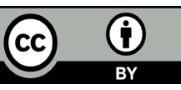

